\title{
Neotypification of two names in Ziziphus (Rhamnaceae)
}

\author{
Avinash R. Gholave1*, Sharad S. Kambale² and S.P. Gaikwad ${ }^{1}$ \\ 'Department of Botany, Walchand College of Arts \& Science, Solapur district, Maharashtra - 413 006, India. \\ 2Department of Botany, MVP Samaj's Arts, Commerce and Science College, Tryambakeshwar, Nashik district, \\ Maharashtra - 422 212, India. \\ *Email: agholave@gmail.com
}

\section{Abstract}

The names Ziziphus horrida Roth and Ziziphus truncata Blatt. \& Hallb. are neotypified.

Keywords: Maharashtra, Neotypification, Rajasthan.

\section{Introduction}

The genus Ziziphus Mill. includes c. 65 species (Mabberley, 2017), of which 17 species and 10 varieties are reported from India (Bhandari \& Bhansali, 2000). During revisionary studies on the genus in India, it has been found that the original materials of the names Ziziphus horrida Roth and Z. truncata Blatt. \& Hallb. are not extant. Hence neotypes are designated according to Art. 9.8 of Shenzhen Code (Turland et al., 2018).

\section{Typification}

Ziziphus horrida Roth in Roem. \& Schult., Syst. Veg. 5: 314. 1819 \& Nov. Pl. Sp. 159. 1821.

Neotype (designated here): INDIA, Maharashtra, Solapur district, Sulewadi, Malshiras, 28.09.2017, A.R. Gholave E S.P. Gaikwad 550 (CAL; isoneotypes, BSI \& SUK).

Fig. 1.

Note: Until now, the protologue of Z. horrida Roth was known to be 'Roth, Nov. Pl. Sp. 159. 1821', which was also followed by Lawson (1875), Cooke (1902) and Bhandari \& Bhansali (1990, 2000). However, we found that Roemer and Schultes (1819) had already validly published Z. horrida in their edition of Systema vegetabilium (Vol. 5, p. 341), with diagnosis followed by "Roth nov. pl. Spec. MSS." As this represents direct association of Roth with both the name and the diagnosis, the name has to be cited as Z. horrida Roth, not Z. horrida "Roem. \& Schult." nor Z. horrida "Roth ex Roem. \& Schult." (cfr. Art 46.3, Ex. 15 in Turland et al., 2018). In fact before the publication of the new taxa of Roth in Novae plantarum species a manuscript copy of Roth's work was available to Roemer and Schultes (Stafleu \& Cowan, 1983).

In the protologue of Z. horrida collection of Benjamin Heyne from 'India orientalis' was cited. Heyne had originally intended to present his set of plants to Willdenow but the latter had died before Heyne's return to Berlin. Heyne then gave the plants to Roth. According to Stafleu and Cowan (1983) the herbarium and types of A.W. Roth are at B and B-Willd (now B-W). It was stated that Roth's main herbarium was in Oldenburg, Germany and was later transferred to B in 1925/26, where it was incorporated into the main collection. The herbarium at Berlin was largely destroyed during the Second World War in 1943. After enquiring the authorities of $\mathrm{B}$ and $\mathrm{B}-\mathrm{W}$ we came to know that there is no such collection in their herbaria. From Stafleu and Cowan (1979) we found the materials of Heyne are at B, BR, CGE, G, GH, H, K and LE. However, we were informed by the authorities of these herbaria that no duplicates of collections by Heyne could be traced. Thus, we have neotypified the name following Art. 9.8 (Turland et al., 2018).

Ziziphus truncata Blatt. \& Hallb., J. Bombay Nat. Hist. Soc. 26: 234. 1918.

Neotype (designated here): INDIA, Rajasthan, Jodhpur district, Kaylana, 19.12.2017, A.R. Gholave \& S.P. Gaikwad 552 (CAL; isoneotypes, BSI, SUK).

Fig. 2.

Notes: Blatter and Hallberg (1918) mentioned "Jodhpur, Kailana (No. 5803!)" in the protologue. Being Blatter was working in the BLAT, we assume that the type could be deposited at BLAT. However, the search for the original material '5803' could not be traced at BLAT and its duplicates at BSI, BSJO, 


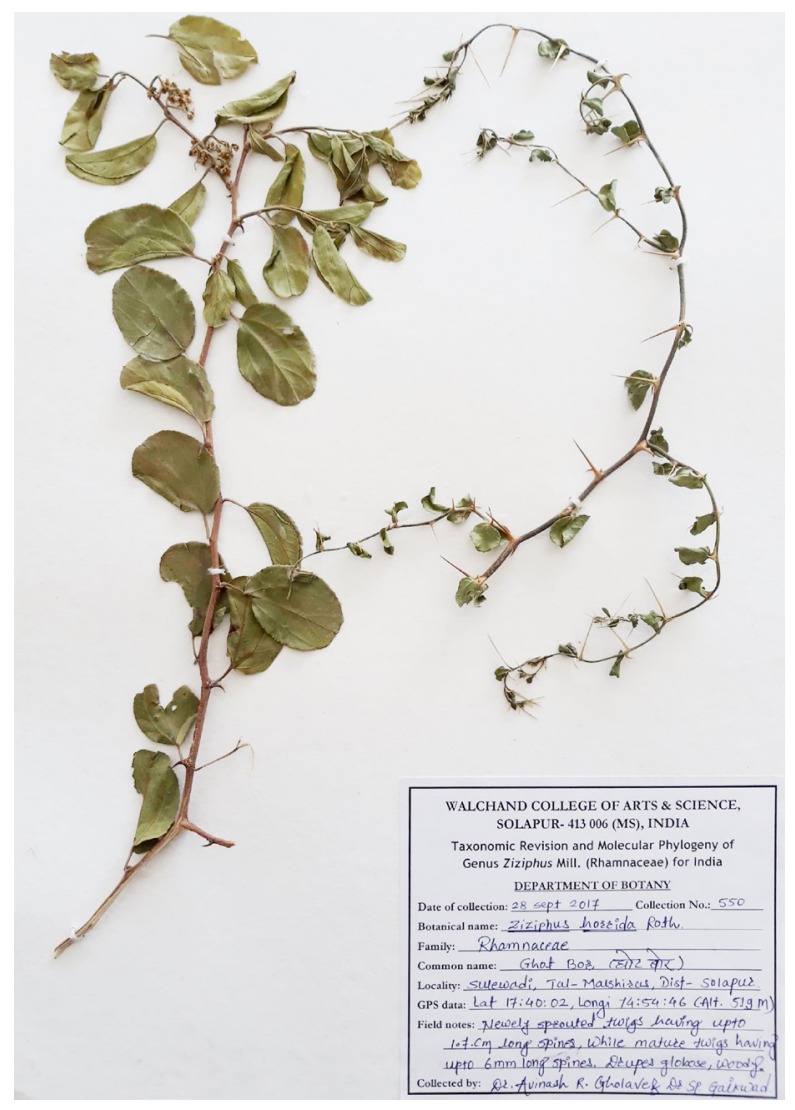

Fig. 1. Neotype of Ziziphus horrida Roth (A.R. Gholave \& S.P. Gaikwad 550, CAL)

CAL and JAC. Thus, in the absence of any original material the name is neotypified based on a specimen collected from the type locality Kaylana (Kailana), following Art. 9.4 and 9.8 of Shenzhen Code (Turland et al., 2018).

\section{Acknowledgements}

Authors are grateful to the Principal, Walchand College of Arts and Science, Solapur; Arts, Commerce \& Science College, Tryambakeshwar for providing facilities; the curators of BLAT, BSI, $\mathrm{BSJO}, \mathrm{CAL}$ and JAC for help rendered during herbarium consultation, curators of $\mathrm{K}$ and $\mathrm{B}$ for the information on type specimens and Dr. Leandro Cardoso Pederneiras, Instituto de Pesquisa do Jardin Botânico do Rio de Janeiro for providing relevant literature. ARG is grateful to the Science and Engineering Research Board (SERB), Department of Science and Technology, New Delhi for financial assistance (SERB/ PDF/2016/001910).

\section{Literature Cited}

Bhandari, M.M. \& A.K. Bhansali 1990. Rhamnaceae. In: Nayar, M.P, Thothathri, K.

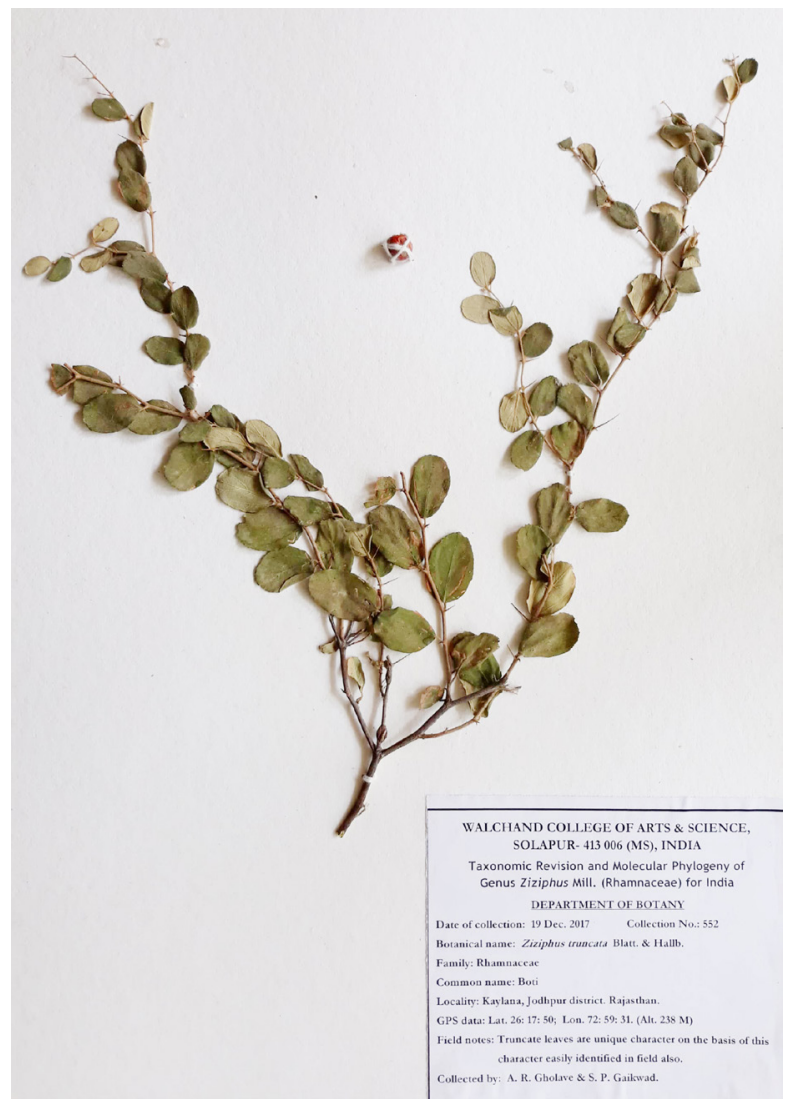

Fig. 2. Neotype of Ziziphus truncata Blatt. \& Hallb. (A.R. Gholave \& S.P. Gaikwad 552, CAL)

\& M. Sanjappa (eds.), Fascicles of Flora of India, Fascicle 20. Botanical Survey of India, Kolkata. pp. 26-114.

Bhandari, M.M. \& A.K. Bhansali 2000. Rhamnaceae. In: Singh, N.P., Vohra, J.N., Hajra, P.K. \& D.K. Singh (eds.), Flora of India. Vol. 5. Botanical Survey of India, Kolkata. pp. 163-245.

Blatter, E. \& F. Hallberg 1918. The flora of the Indian Desert (Jodhpur and Jaisalmer). J. Bombay Nat. Hist. Soc. 26: 218-246.

Cooke, T. 1902. The Flora of the Presidency of Bombay. Vol. 1. Taylor \& Francis, London. p. 258.

Lawson, M.A. 1875. Ziziphus Mill. In: Hooker, J.D. (ed.), The Flora of British India. Vol. 1. L. Reeve \& Co., London. pp. 632-637.

Mabberley, D.J. 2017. The Plant-Book: A portable dictionary of plants, their distribution and uses. Fourth Edition. Cambridge University Press, Cambridge.

Roemer, J.J. \& J.A. Schultes 1819. Pentandria monogynia, Caroli a Linné equitis systema 
vegetabilium: secundum classes, ordines, genera, species cum characteribus, differentiis et synonymiis. Vol. 5. J.G. Cottae, Stuttgardtiae. p. 341. http:// botanicus.org/item/31753002065792

Roth, A.W. 1821. Novae Plantarum Species praesertim Indiae Orientalis. H. Vogleri, Halberstadt. p. 159.

Stafleu, F.A. \& R.S. Cowan 1979. Taxonomic Literature. Second edition. Vol. 2. Bohn, Scheltema \& Holkema, Utrecht, Dr. W. Junk B.V., Publishers, The Hague.

Stafleu, F.A. \& R.S. Cowan 1983. Taxonomic Literature. Second edition. Vol. 4. Bohn, Scheltema \& Holkema, Utrecht, Dr. W. Junk B.V., Publishers, The Hague/Boston.
Turland, N.J., Wiersema, J.H., Barrie, F.R., Greuter, W., Hawksworth, D.L., Herendeen, P.S., Knapp, S., Kusber, W.H., Li, D.Z., Marhold, K., May, T.W., McNeill, J., Monro, A.M., Prado, J., Price, M.J. \& G.F. Smith (eds.) 2018. International Code of Nomenclature for algae, fungi, and plants (Shenzhen Code). Regnum Vegetabile 159. Koeltz Botanical Books, Glashütten. DOI https://doi.org/10.12705/Code.2018

Received: 12.04 .2018

Revised and Accepted: 07.12.2018 